\author{
Agnieszka Goral \\ Uniwersytet Marii Curie-Skłodowskiej w Lublinie (Polska) \\ Maria Curie-Skłodowska University in Lublin (Poland) \\ e-mail: a.goral@poczta.umcs.lublin.pl
}

https://orcid.org/0000-0003-1622-970X

\title{
Dewerbalne osobowe nomina subiecti z formantem słowotwórczym -нік (-льнік) w języku białoruskim
}

Deverbal personal nomina subiecti with the suffix "-nik" (,-Inik") in the Belarusian language

Аддзеяслоўныя асабовыя nomina subiecti з суфіксам „-нік" (,-льнік") у беларускай мове

\begin{abstract}
This article is devoted to the semantic and derivational analysis of masculine deverbal nouns belonging to the category of nomina subiecti with the suffix -nik (-lnik) in the Belarusian language. The notion nomina subiecti comprises the designations of people who perform some work or occupation, whether permanent or temporary, with or without material gain. The names analyzed, whose derivational meaning can be defined as „he or she who performs the activity associated with the verb that serves as the derivational basis", are a collection of 228 Belarusian personal derivatives, taken from Belarusian and Polish dictionaries, lexicographic works in the field of synchronic word-formation of personal names, and the author's own materials. From the point of view of semantics, this category of derivatives represents vocabulary belonging to the sphere of everyday life, including both designations of professions and performers of temporary or occasional activities, and these names are rooted in the Belarusian language's derivational system, as they designate the performers of agricultural, industrial and craft activities. The analysis proved that, in Belarusian, the group of personal deverbal nomina subiecti with the suffix -nik (-lnik) is large, yet, at the present stage of development of the language, the formant nik (-lnik) is practically no longer used to create designations of professions. The relatively small amount of neologisms proves that this formant is less popular than other suffixes, especially foreign ones (cf. -ant, -ist), and this applies above all to the sphere of politics, mass culture, and sport; when it comes to its structure, the suffix shows connectivity with the native word-formation bases, and the process of derivation is characterized by a considerable degree of regularity.
\end{abstract}

Keywords: Belarusian derivates, deverbal nouns, derivational formant, nomina subiecti, personal nouns 


\begin{abstract}
Abstrakt
Artykuł został poświęcony analizie semantycznej i słowotwórczej dewerbalnych rzeczowników rodzaju męskiego należących do kategorii nomina subiecti z formantem słowotwórczym -нік (-льнік) w języku białoruskim w ujęciu synchronicznym. Pod pojęciem nomina subiecti rozumiane są nazwy osób wykonujących jakąś pracę lub podejmujących jakieś zajęcie, przy czym praca ta może mieć charakter stały bądź tymczasowy, zarobkowy lub niezwiązany z korzyściami materialnymi. Analizowane nazwy, których znaczenie słowotwórcze można ująć w peryfrazie 'ten, kto wykonuje czynność związaną z czasownikiem będącym podstawą słowotwórczą', stanowią zbiór 228 białoruskich derywatów osobowych, zaczerpniętych z białoruskich i polskich słowników, prac leksykograficznych z zakresu słowotwórstwa synchronicznego nazw osobowych oraz materiałów własnych autora. Z punktu widzenia semantyki badana kategoria derywatów reprezentuje słownictwo należące do sfery życia codziennego, obejmujące zarówno nazwy zawodowe, jak i nazwy subiektów czynności tymczasowych i okazjonalnych, przy czym są to nazwy zakorzenione w systemie słowotwórczym języka białoruskiego, oznaczające wykonawców czynności rolniczych, przemysłowych, rzemieślniczych. Przeprowadzona analiza dowiodła, że w języku białoruskim grupa osobowych dewerbalnych nomina subiecti z sufiksem -нік (-льнік) stanowi zbiór liczny, jednak na obecnym etapie rozwoju języka formant -нік (-льнік) praktycznie nie tworzy nazw zawodowych. Stosunkowo niewielki zbiór neologizmów dowodzi, że przegrywa on w rywalizacji z innymi sufiksami, zwłaszcza obcymi (por. -aнm, -icm), a dotyczy to przede wszystkim polityki, kultury masowej, sportu. Z kolei ze względu na budowę badany sufiks wykazuje łączliwość z rodzimymi podstawami słowotwórczymi, a proces derywacji cechuje znaczny stopień regularności.
\end{abstract}

Słowa kluczowe: słowotwórstwo białoruskie, rzeczowniki dewerbalne, formanty słowotwórcze, nomina subiecti, nazwy osobowe

\title{
Анатацыя
}

Артыкул прысвечаны семантычнаму і словаўтваральнаму аналізу аддзеяслоўных назоўнікаў мужчынскага роду з суфіксам -нік (-льнік), якія ў беларускай мове належаць да катэгорыі nomina subiecti. Пад тэрмінам nomina subiecti аўтар разумее назвы асоб, якія выконваюць сталую або часовую працу, звязаную $з$ матэрыяльнымі або нематэрыяльнымі выгадамі. Назоўнікі са значэннем 'той, хто выконвае дзеянне паводле словаўтваральнага дзеяслова' складаюць групу 228 намінацый, выбраных з беларускіх слоўнікаў, лексікаграфічных публікацый у галіне мовазнаўства, а таксама матэрыялаў аўтара. 3 семантычнага пункту гледжання даследаваныя назвы адносяцца да розных сфер дзейнасці з галіны прамысловасці, сельскай гаспадаркі, эканомікі, адукацыі, культуры, рэлігіі, сферы паўсядзённага жыцця. Аналіз паказаў, што ў лексічным корпусе беларускай мовы аддзеяслоўныя назоўнікі з суфіксам -нік (-льнік) утвараюць значную групу, аднак на сучасным этапе развіцця мовы суфікс -нік (-льнік) практычна не ўтварае новых намінацый паводле прафесіі. Адносна невялікая колькасць неалагізмаў сведчыць пра тое, што фармант прайграе ў канкурэнцыі з іншымі суфіксамі, асабліва іншамоўнага паходжання (напр.: -aнm, -icm), і гэта тычыцца ў першую чаргу сферы палітыкі, масавай культуры, спорту. Як 
вынікае з аналізу, у беларускай мове суфікс -нік (-льнік) спалучаецца з асновамі славянскага паходжання, а працэс дэрывацыі характарызуе значная ступень рэгулярнасці.

Ключавыя словы: беларускае словаўтварэнне, аддзеяслоўныя назоўнікі, словаўтваральныя суфіксы, nomina subiecti, асабовыя назвы

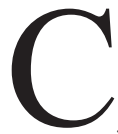

elem artykułu jest analiza semantyczna i słowotwórcza dewerbalnych rzeczowników z formantem słowotwórczym -нік (-льнік) we współczesnym języku białoruskim. Zebrany korpus leksykalny obejmuje nazwy osób rodzaju męskiego należące do kategorii wykonawców czynności (nomina subiecti). Pod pojęciem nomina subiecti rozumiane są nazwy osób wykonujących jakąś pracę lub podejmujących jakieś zajęcie, przy czym praca może mieć charakter stały (por. кіраўнік, махальнік, працаўнік, размеркавальнік, зрыўнік) bądź tymczasowy (por. карыстальнік, наведвальнік, наглядальнік, наладжвальнік, паведамляльнік, пазычальнік pot.), zarobkowy (por. будаўнік, вальцавальнік, працауинік, разнік, распаўсюднік) lub niezwiązany z korzyściami materialnymi (por. адпраўнік, карыстальнік, наведвальнік, наглядальнік, назіральнік). Analizowane nazwy można ująć w peryfrazie 'ten, kto wykonuje czynność związaną z czasownikiem będącym podstawą słowotwórczą' ${ }^{1}$. Ograniczenie zakresu znaczeniowego kategorii osobowych nomina subiecti do nazw agentywnych pozwoliło wyłączyć z analizy nazwy atrybutywne, por. адмоўнік 'ten, kto uchyla się (od obowiązku służby wojskowej)', бабнік 'babiarz, kobieciarz', блукальнік 'ten, kto ma w zwyczaju wałęsać się, błąkać się’, гуляннік 'hulaka', жартаўнік 'żartowniś, kpiarz'.

Łącznie badaniu poddano 228 derywatów osobowych, które wyekscerpowano z wydanych na Białorusi i w Polsce słowników języka białoruskiego (Krapiwa, 19771984; Bułyka, 1999, 2005; Ułasiewicz, Dauhulewicz, 2009; Kaurus, 2013; Bartoszewicz, Komendacka, 1988), białoruskich oraz polskich prac leksykograficznych z zakresu słowotwórstwa synchronicznego nazw osobowych (białoruskie: Chackiewicz, 1956; Waranowicz, 1997, 2005; Łukaszaniec, 2001, 2009, 2013; Rusak, 2002, 2003a, 2003b; Siegień, 2007; Maczaława, 2013; polskie: Witkowski, 1955; Borowiec, 2009; Chomko, 2007; Goral, 2013a, 2013b i in.) oraz materiałów własnych autora, ponadto w analizie uwzględniono wyniki badań z zakresu słowotwórstwa nazw osobowych języków wschodniosłowiańskich lingwistów rosyjskich (Maksimow, 1975; Biełousowa, 1981; Akopian, 1990; Władimirowa, 1991; Achmatjanowa, 2000; Jakowlewa, 2010).

Formant słowotwórczy (FS) -нік (-льнік) należy do najbardziej produktywnych w językach wschodniosłowiańskich, co potwierdzają badania zarówno językoznawców polskich (por. Smułkowa, 1992; Waszakowa, 1994; Kaliszan, 2000; Sajewicz,

1 Szerzej o terminie nomina subiecti oraz jego synonimach piszę w monografii Derywacja sufiksalna... (Goral, 2013, s. 19-20). 
2002; Chomko, 2007; Borowiec, 2009; Goral 2013a, 2013b), jak i białoruskich (por. Waranowicz, 1997, 2005; Łukaszaniec, 2001, 2009, 2013; Rusak, 2002, 2003a, 2003b; Siegień, 2007; Maczaława, 2013). Według Łarisy Władimirowej w języku prasłowiańskim za pomocą FS -нiк były tworzone wyłącznie nazwy osobowe, dopiero później urabiał on także rzeczowniki nieosobowe: nazwy urządzeń i narzędzi (Władimirowa, 1991, s. 50). Jak podaje Alena Maczaława (2013, s. 15-16), w XX w. na bazie sufiksu -нік powstał FS -льнік, wykorzystywany w nazwach wykonawców czynności, które według Gienadija Artemionka (1988, s. 16) - „з этымалагічнага пункту гледжання 3'яўляюцца словаўтваральнымі калькамі рускіх намінацый з суфіксам «-тель»".

W badaniach Maczaławej (2013, s. 24) derywaty osobowe z FS -нік (-льнік) stanowią $17,1 \%$ i znajdują się na trzeciej pozycji pod względem liczebności w kategorii nazw subiektów czynności, zaraz po sufiksach -чык // -шчыাк, -льшчыл (30\%) oraz-icm // -blcm (22,1\%). Wysoką produktywność FS -нік (-льнік) w słowotwórstwie nazw osobowych (zwłaszcza neologizmów) potwierdzają badania Waleryja Waranowicza, który stwierdza, że „найбольш прадуктыўным суфіксам пры ўтварэнні неалагізмаў у апошні час 3'яўляецца суфікс «-нік». Наватвораў з гэтым суфіксам намі зафіксавана найбольш як пры аддзеяслоўным, так і пры адсубстантыўным утварэнні (адпаведна 69 і 27)" (2000, s. 50). Zjawisko ekspansji formantu odnotowali także autorzy słowników, włączając do korpusu leksykalnego m.in. takie nowo powstałe derywaty, jak адведнік neol. 'ten, kto (kogoś) odwiedza', адпачнік neol. 'ten, kto odpосzуша', выкладнік neol. 'ten, kto (coś) wykłada, układacz', выпллатнік neol. 'ten, kto coś wypłaca', наведвальнік neol. 'ten, kto odwiedza (kogośs)', распаўсюджвальнік neol. 'ten, kto rozpowszechnia (coś), kolporter' (por. Kaurus, 2013, s. 24; Waranowicz, 2005, s. 53).

W języku białoruskim za pomocą FS -нік (-льнік) tworzone są zarówno nazwy osobowe (por. dewerbalne: адведнік 'odwiedzający', адпраўнік 'nadawca', атрымальнік 'odbiorca', заснавальнік 'założyciel, fundator', шукальнік 'poszukiwacz, odkrywca'; desubstantywne: дачнік 'działkowicz, letnik', мечнік hist. 'ten, kto nosił miecz', шабельнік hist. 'ten, kto wyrabiał szable, płatnerz', школьнік 'uczeń'), jak i nieosobowe (por. грэйнік 'grzejnik', дашчанік 'budowla lub łódka z desek', жабнік 'naczynie do hodowli żab (w laboratorium)', карчавальнік 'urządzenie do rozdrabniania karp krzewów', паглььбнік 'urządzenie do pogłębienia lub wykopu (rowu, dołu)', награвальнік 'grzejnik', падагравальнік 'podgrzewacz (wody)', палубнік 'grube płyty lub deski do budowy pokładu statku', прайгравальнік 'magnetofon z funkcją przegrywania', трэбнік 'księga rytuałów'), przy tym podstawami słowotwórczymi formacji z omawianym sufiksem mogą być rzeczowniki (por. бяседнік 'uczestnik przyjęcia, biesiady' бяседа, газетнік 'sprzedawca gazet' $\leq$ газета, лірнік 'ten, kto gra na lirze' $\leq$ ліра, эстраднік 'ten, kto występuje na estradzie' $\leq$ эстрада), czasowniki (por. абклейнік 'ten, kto okleja (coś)', будаўнік 'budowlaniec', ваёунік 'wojak', прад'яўнік 'okaziciel', працаўнік 'pracownik'; выкрывальнік 'wykrywса', вылічальнік 'księgowy', вырабляльнік 'wytwórca', капальнік 'ten, kto wykopuje (ziemniaki)'), przysłówki (por. заўсёднік рot. 'ten, kto jest stałym bywalcem (gdzieś)' $\leq$ заўсёды), a nawet związki wyrazowe (por. wyrażenia zaimkowe: наморднік 'раменная сетка, якая надзяваецца на 
морду сабак або іншых жывёл’, налобнік ‘тое, што завязваецца на галаву (на ілбе) для падтрымкі валасоў у час работы').

W języku białoruskim dewerbalne derywaty osobowe z FS -нік (-льнік) stanowią grupę zróżnicowaną z punktu widzenia semantyki i reprezentują zarówno nazwy zawodowe, jak i zwyczajowe (por. Artiemienok, 1988; Akopian, 1990; Gorbaczik, 1993; Waranowicz, 1997, 2005; Łukaszaniec, 2014). W zbiorze nomina subiecti największą grupę stanowią nazwy osób ze względu na pełnione funkcje i usługi wykonywane w celach zarobkowych lub dla uzyskania różnego rodzaju korzyści niematerialnych, por. кіраўнік 'kierownik', махальнік 'sygnalista (na lotnisku)', праиаўнік 'pracownik', размеркавальнік 'ten, kto kieruje do pracy zgodnie z rejonizacją', разнік 'masarz', распаўсюднік 'kolporter', спаведнік 'spowiednik', транспартнік ${ }^{3}$ 'transportowiec, logistyk', узрыўнік 'saper', вальцавальнік 'walcownik', вешальнік arch. 'egzekutor', выкрывальнік 'wykrywca', вылічальнік 'księgowy', вырабляльнік 'wytwórca', a także заклінальнік, калібравальнік, ператваральнік, распаўсюджвальнік, распрачоўнік, спавядальнік, сумяшчальнік, узнаўляльнік, укладальнік, укрывальнік, фрахтавальнiк. Ten różnorodny semantycznie zbiór derywatów obejmuje także nazwy reprezentujące takie dziedziny życia człowieka, jak kultura, nauka i sztuka (por. абследавальнік 'badacz', адкрывальнік 'odkrywса', апавядальнік 'narrator, przewodnik', апавяччальнік teatr. arch. 'zapowiadacz', апісальнік książk. 'narrator', асвятляльнік teatr. 'ten, kto oświetla (scenę)', асэнсавальнік 'ten, kto opisuje, thumaczy (historię)', выпрабавальнік 'eksperymentator', выстуупальнік neol. 'artysta', даследнік neol. 'badacz', перакладнік ${ }^{4}$ neol. 'przekładowca, tłumacz', тваральнік 'twórca', тлумачальнік 'tłumacz'), introligatorstwo i sfera wydawnicza (por. афармляльнік, друкавальнік neol., кадзіравальнік, складальнік), ochroniarstwo i dozór (por. ахавальнік, ахоўнік, вартаўнік, хавальнік), sport (por. кідальнік, разыгрывальнік, ратавальнік, штурхальнік), rolnictwo (por. збіральнік 'zbieracz (plonów)', капальнік 'ten, kto wykopuje (ziemniaki)', раскідвальнік 'ten, kto rozrzuca lub sieje (ziarno)', сартавальнік 'sortowacz (jabłek)'), przemysł budowlany i remontowy (por. абклейнік 'ten, kto okleja (coś)', будаўнік 'budowlaniec', рамонтнік 'remontowiec'), rzemiosło (por. лудзільнік 'emalier', скрабнік 'cieśla', цьиляввальнік 'cykliniarz'), architektura (por. азеляняльнік 'projektant krajobrazu', праектавальнік 'projektant'), przemysł ciężki (por. абагачальнік techn. 'ten, kto wzbogaca (metale)', гартавальнік 'hartownik', літавальнік arch. 'spawacz') oraz

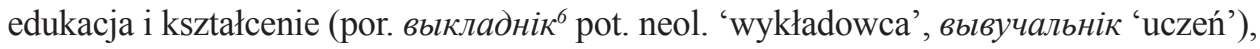
rękodzieło (por. стругальнік 'rzeźbiarz'), sektor ubezpieczeniowy (por. страхавальнік 'ubezpieczyciel').

Możliwa także motywacja odrzeczownikowa (споведзь $\geq$ спаведнік).

Możliwa także motywacja odrzeczownikowa (трансnарm $\geq$ трансnартнік).

Możliwa także motywacja odrzeczownikowa (пераклад $\geq$ перакладнік neol.).

Możliwa także motywacja odrzeczownikowa (рамонт $\geq$ рамонтнік).

6 Możliwa także motywacja odrzeczownikowa (выклад $\geq$ выкладнік pot. neol.) 
Z kolei do zwyczajowych nomina subiecti należy zaliczyć derywaty określające osoby z punktu widzenia czynności tymczasowych, krótkotrwałych, okazjonalnych, wykonywanych nie w sposób zarobkowy. Do nazw zwyczajowych należą zarówno derywaty z FS -нік (por. адпраўнік 'nadawca', адыххонік 'ten kto na jakiś czas opuszcza swoje miejsce zamieszkania w celach zarobkowych', вандроўнік 'wędrowiec, kolędnik', ваёўнік

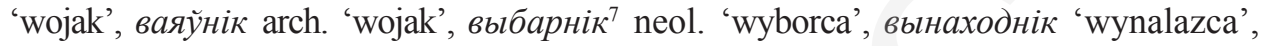
выплатнік neol. 'płatnik', заяўнік 'ten, kto ogłasza (coś)', каляднік 'kolędnik', нападнік 8 'agresor', падробнік 'fałszerz', прад’яўнік 'okaziciel'), jak i FS -льнік (por. аглядальнік 'widz', адведвальнік neol. 'odwiedzający', адпачыввальнік neol. 'letnik', выкрадальнік 'złodziej', наймальнік 'najemca', a także вышукальнік, вязальнік, давальнік neol., глушыльнік, захавальнік, заяўляльнік, здзяйсняльнік, карыстальнік, наведвальнік, наглядальнік, назіральнік, наладжвальнік, паведамляльнік, пазычальнік pot., патрабавальнік, разведвальнік, распавядальнік, суправаджальнік, утаймавальнік, чакальнік, чьттальнік).

W zebranym korpusie leksykalnym przeważającą większość stanowią wyrazy nienacechowane stylistycznie, odnotowano jedynie kilka neologizmów (por. адведвальнік neol. 'odwiedzający', адведнік neol. 'odwiedzający', адпачнік neol. 'ten, kto wyросzуwа (w sanatorium), kuracjusz', адпачывальнік neol. 'letnik', выбарнік nеol. 'wyborca', выплатнік neol. 'płatnik', давальнік neol. друкавальнік neol. 'drukarz', фехтавальнік neol. 'szermierz'), archaizm (por. літавальнік arch. 'spawacz') oraz rzeczownik potoczny (por. пазычальнік pot.). Za neologizmy uznawane są derywaty z FS -ннік, por. адпачыннік ${ }^{9}$ neol. 'ten, kto wyросzуwa (nad morzem)', глядзеннік neol. 'telewidz', складаннік poligr. neol. 'introligator'.

Wysoka produktywność analizowanego FS determinuje jego rywalizację z innymi sufiksami (por. Goral, 2011, s. 83-94). Konkurujące ze sobą pary FS reprezentują następujące typy:

а) FS -нік - FS -шчык, por. адпраўнік - адпраўшчык, аклейнік - аклейшчык, апальнік - апальшчык, бунтаўнік - бунтаўшчык, выбарнік neol. выбаршчык, настройнік - настройшчык, паліройнік - паліроўшчык, скупнік - скупшчьк,

b) FS -нік - FS -чылк, por. вылладнік neol. - выклладчык, вознік - возчык, нагляднік - наглядчык, падказнік - падказчык, перавознік - перавозчык,

с) FS -льнік - FS -льшчьік, рог. вязальнік - вязальшчык, літавальнік літавальшчык, тачыльнік - тачыльшчык, шліфавальнік-шліфавальшчык,

d) FS -льнік - FS -шчык, por. вальцавальнік - вальцоуцичык, праектавальнік - праекиіроўшчык, свідравальнік - свідроўшчык,

е) FS -льнік - FS -льшчыюк, por. прыбіральнік - прыбіральшчык,

f) FS -льнік - FS -чык, por. аглядальнік - аглядчык.

\footnotetext{
Możliwa także motywacja odrzeczownikowa (выбары $\geq$ выбарнік nеol.).

8 Możliwa także motywacja odrzeczownikowa (напад $\geq$ нападнік).

9 Możliwa także motywacja odrzeczownikowa (адпачын arch., адпачынак $\geq$ адпачыннік nеol.).
} 
Ponadto FS -нік, -льнік, -ннік, -ельнік konkurują z FS -ец (por. спажывальнік - спажывеи), FS -(оў)ца (por. выннаходнік - вынаходия, выступальнік пеol. выступоуциа nеol., нападальнік, нападнік-нападоуица), FS -ак (por. вознік-вазак), FS -ар (por. друкавальнік pot. - друкар), FS -цель (por. выхавальнік - выхавацель), FS zerowy (por. адзінота - адзінотнік). Niektóre podstawy słowotwórcze wykazują łączliwość nie tylko z FS -нік, -льнік, ale także z innymi sufiksami, por. адпачнік, адпачыннік, адпачыввальнік, адпачыьванец, адпачыншчык; выступальнік neol. выступоуца neol. - выступанец neol. - выступовеи neol. Najsilniejszym konkurentem formacji z FS -нік jest sufiks -чblк // -шчыıк, co potwierdzają badania Waranowicza, który stwierdza, że FS „«-нік», «-льнік» найчасцей быў выкарыстаны ў зафіксаваных намі наватворах на месцы суфікса «-чык» // «-шчык» (у тым ліку фарманта «-льшчык»)" (Waranowicz, 2005, s. 53).

Liczne rzeczowniki z formantem -нiк podlegają neutralizacji semantycznej: mogą oznaczać zarówno nazwy osobowe nomina subiecti, jak i nazwy maszyn, narzędzi i urządzeń (por. выллічальнік 1. 'ten, kto oblicza (coś)', 2. 'maszyna, która oblicza (coś)'; сартавальнік 1. 'ten, kto sortuje (towar)', 2. 'maszyna, która sortuje (towar)'; шукальнік 1. 'ten, kto szuka (czegoś)', 2. 'narzędzie lub urządzenie, które szuka (obiektów)'), substancji (por. узнаўляльнік 1. 'ten, kto wznawia (coś)', 2. 'substancja, która przywraca (kolor, połysk)'), instytucji (por. атрымальнік 1. 'ten, kto otrzymuje (coś)', 2. 'instytucja, która otrzymuje (coś)'), roślin (por. шабельнік 1. arch. 'ten, kto wyrabia szable', 2. 'pięciornik') lub należeć do kilku grup semantycznych (por. размеркавальнік 1. 'ten, kto przydziela (coś)', 2. 'instytucja, która przydziela (coś)', 3. 'urządzenie, dozujące jakieś substancje (gaz, prąd)', 4. arch. 'sklep, który realizuje przydział'). O przynależności znaczeniowej derywatu może decydować także znaczenie, por. 1. мýчанік 'ten, kto doznaje lub doznał mąk (na tle religijnym lub światopoglądowym)', 2. мучáнік 'ludowa nazwa mącznicy lekarskiej'. Zjawisko polisemii derywatów, takich jak: вылічальнік 1. 'ten, kto wylicza (coś)', 2. 'maszyna, która wylicza (coś)', атрыммальнік 1. 'ten, kto otrzymuje (coś)', 2. 'instytucja, która otrzymuje (coś)', сартавальнік 1. 'ten, kto sortuje (towar)', 2. 'maszyna, która sortuje (towar)' oraz innych poszerza się w ostatnim okresie w związku z rozwojem techniki i przemysłu, a co za tym idzie - zwiększeniem w języku zapotrzebowania na leksykę specjalistyczną.

Z uwagi na budowę słowotwórczą nomina subiecti cechuje znaczny stopień regularności. Dewerbalne derywaty z FS -льнік powstają od pełnych podstaw słowotwórczych, zakończonych na samogłoskę, por. захавачь $\geq$ захавальнік, махаиь $\geq$ махальнік, наглядащь $\geq$ наглядальнік, размеркаващь $\geq$ размеркавальнік. Z kolei jeżeli podstawa kończy się na spółgłoskę (niekiedy w rezultacie ucięcia cząstek tema-

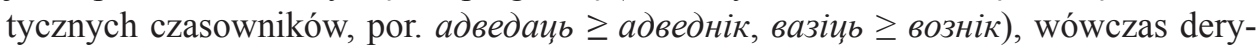

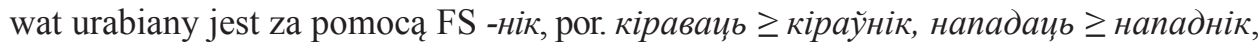
перакладащь $\geq$ перакладнік nеol., рэзаџь $\geq$ разнік, распраиоўващь $\geq$ распраиоўнік, растачыць $\geq$ расточнік.

Procesowi derywacji osobowych nazw subiektów czynności z FS -нiк towarzyszy skrócenie podstaw słowotwórczych o regularne ucięcia samogłosek tematycznych: 


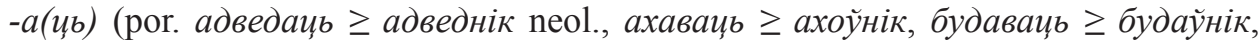

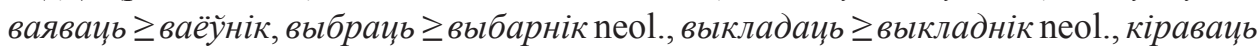
$\geq$ кіраўнік, нападащь $\geq$ нападнік, перакладащь $\geq$ перакладнік пеоl., пращаващь $\geq$ працаўнік, распрацаваџь $\geq$ распрачоўнік, ратавачь $\geq$ ратаўнік, рэзащь $\geq$ разнік,

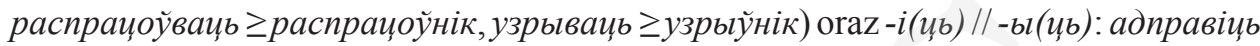
$\geq$ адпраўнік, вазіщь $\geq$ вознік, выплаціиь $\geq$ выплатнік пеоl., лудзіщь $\geq$ лудзільнік, адпачыць $\geq$ адпачнік nеol., пазычыщь $\geq$ пазычнік пеol., прад'явіщь $\geq$ прад'яўнік, растачыць $\geq$ расточнік, распаўсюдзіщь $\geq$ распаўсюднік, a także ucięcia morfu -ава(иь): даследаваць $\geq$ даследнік пеоl., калядаващь $\geq$ каляднік, рамантаваџь $\geq$ рамонтнік, транспартаваць $\geq$ транспартнік.

W badanym korpusie leksykalnym zanotowano następujące alternacje samogłoskowe i spółgłoskowe:

$a \rightarrow o$ (por. вазіиь $\geq$ вознік, ваявачь $\geq$ ваёуннік, растачыць $\geq$ расточнік),

$a \rightarrow$ э por. спавядаць $\geq$ спаведнік),

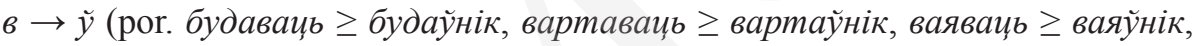
кіраваџь $\geq$ кіраўнік, прачавачь $\geq$ праиаўнік, ратаваџь $\geq$ ратаўнік, узрываџь $\geq$ узрыцинік),

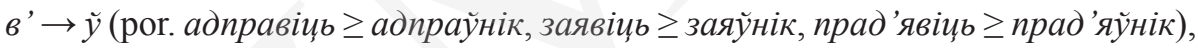

дз' $\rightarrow \partial$ (por. вынаходзіиь $\geq$ выннаходнік, распаўсюдзіщь $\geq$ распаўсюднік nеol.),

u’ $\rightarrow m$ (por. выплаціиц $\geq$ выплатнік neol.),

э $\rightarrow a$ (por. рэзаиь $\geq$ разнік, скрэбиі $\geq$ скрабнік),

ав $\rightarrow$ оў (рог. ахаващь $\geq$ ахоўнік, вандраващь $\geq$ вандройнік, распращаващь $\geq$ распраџоўнік neol.).

Przeprowadzona analiza dowodzi, że w języku białoruskim grupa osobowych dewerbalnych nomina subiecti z FS -нік (-льнік) stanowi zbiór liczny, uzupełniany o nowe jednostki leksykalne ${ }^{10}$. Z punktu widzenia semantyki badana kategoria derywatów reprezentuje słownictwo należące do sfery życia codziennego, obejmujące zarówno nazwy zawodowe, jak i nazwy subiektów czynności tymczasowych i okazjonalnych, przy czym są to nazwy trwale funkcjonujące w systemie słowotwórczym języka białoruskiego, oznaczające wykonawców czynności rolniczych, przemysłowych, rzemieślniczych. Obecnie omawiany formant praktycznie nie tworzy nazw zawodowych, a stosunkowo niewielki zbiór neologizmów dowodzi, że pomimo wysokiej, trzeciej pozycji na liście rankingowej białoruskich sufiksów agentywnych (Maczaława, 2013) FS -нік (-льнік) wyraźnie ustępuje innym formantom, zwłaszcza obcym (por. - $-a \mu m,-i c m$ ), a dotyczy to przede wszystkim sfery polityki, kultury masowej, sportu. Ze względu na budowę sufiks wykazuje łączliwość z rodzimymi podstawami słowotwórczymi, a proces derywacji cechuje znaczny stopień regularności.

10 Według Waranowicza we współczesnym języku białoruskim na wysoką produktywność FS -нiк wpływają dwa czynniki: „суфiкс «-нік», які шырока выкарыстоўваўся для ўтварэння потіna agentis, з'яўляецца ўжо поліфункцыянальным; суфікс «-нік» набывае больш выразную агентыўнасць” (2005, s. 121). 


\section{Bibliografia}

\section{Źródla}

Bartoszewicz, Albert, Komendacka, Irena. (1988). Słownik a tergo współczesnego języka białoruskiego. T. 2. Warszawa: Wydawnictwo Uniwersytetu Warszawskiego.

Bułyka, Alaksandr (red.). (1999). Słounik inszamounych słou. Minsk: Biełaruskaja encykłapiedyja. [Булыка, Аляксандр (рэд.). (1999). Слоўнік іншамоўных слоў. Мінск: Беларуская энцыклапедыя].

Bułyka, Alaksandr (red.). (2005). Stounik inszamounych słou. Aktualnaja leksika. Minsk: Biełaruskaja encykłapiedyja. [Булыка, Аляксандр (рэд.). (2005). Слоўнік іншамоўных слоў. Актуальная лексіка. Мінск: Беларуская энцыклапедыя].

Kaurus, Aleś (red.). (2013). Stowakład: stounik admietnaj leksiki. Minsk: Wydawiecki dom „Zwiazda”. [Каўрус, Алесь (рэд.). (2013). Словаклад: слоўнік адметнай лексікі. Мінск: Выдавецкі дом „Звязда”].

Krapiwa, Kandrat (red.). (1977-1984). Ttumaczalny stounik biełaruskaj mowy. T. 1-5. Minsk: Biełaruskaja Sawieckaja Encykłapiedyja. [Крапіва, Кандрат (рэд.). (19771984). Тлумачальны слоўнік беларускай мовы. Т. 1-5. Мінск: Беларуская Савецкая Энцыклапедыя].

Ułasiewicz, Wiktoryja, Dauhulewicz, Natalla (red.). (2009). Słounik nowych słou biełaruskaj mowy. Minsk: TietraSistiems. [Уласевіч, Вікторыя, Даўгулевіч, Наталля (рэд.). (2009). Слоўнік новых слоў беларускай мовы. Мінск: ТетраСистемс].

\section{Opracowania}

Achmatjanowa, Ziemfira. (2000). Suszczestwitielnyje „nomina agentis” w sowriemiennom russkom jazykie. Awtorefierat dis. [...] kand. fitot. nauk. Ufa: Baszkirskij gos. uniwiersitiet. [Ахматьянова, Земфира. (2000). Существительныле „nотіna agentis” в современном русском языке. Автореферат дис. [...] канд. филол. наук. Уфа: Башкирский гос. университет].

Akopian, Armienui. (1990). Siemantika otgłagolnych suszczestwitielnych. W: Albina Trawkina (red.). Problemy izuczienija słowa: siemantika, struktura, forma: sb. naucz. tr. (s. 60-68). Twier: Twier. gos. uniwiersitiet. [Акопян, Арменуи. (1990). Семантика отглагольных существительных. В: Альбина Травкина (ред.). Проблемы изучения слова: семантика, структура, форма: сб. науч. тр. (с. 60-68). Тверь: Твер. гос. университет].

Artiemienok, Giennadij. (1988). Stanowlenije słowoobrazowatielnoj mikrosistiemy imieni suszczestwitielnogo $w$ sowriemiennom biełorusskom jazykie: po dannym leksikografii XIX-XX wiekow. Awtorefierat dis. [...] kand. fitot. nauk. Minsk: Akad. Nauk BSSR In-t jazykoznanija im. J. Kołasa (Na prawach rukopisi). [Артеменок, Геннадий. (1988). Становление словообразовательной микросистемь имени существительного в современном белорусском языке: по данным лексикографии ХІХ-ХХ веков. Автореферат дис. [...] канд. филол. наук. Минск: Акад. наук БССР, Ин-т языкознания им. Я. Коласа (На правах рукописи)]. 
Biełousowa, Ałła. (1981). Russkije imiena suszczestwitielnyje so znaczenijem lica. Woprosy jazykoznanija, 3, s. 71-84. [Белоусова, Алла. (1981). Русские имена существительные со значением лица. Вопросы языкознания, 3, с. 71-84].

Borowiec, Agnieszka. (2009). Dewerbalne „nomina agentis” we współczesnym języku białoruskim. W: Michał Kondratiuk, Bazyli Siegień (red.). Polsko-białoruskie zwiazki językowe, literackie, historyczne i kulturowe. Materiały XVI Międzynarodowej Konferencji Naukowej. Droga ku wzajemności (s. 119-128). Białystok: Wydawnictwo Uniwersytetu w Białymstoku.

Chackiewicz, Wiera. (1956). Suffiksalnoje stowoobrazowanije suszczestwitielnych (suffiksy lica) w sowriemiennom biełorusskom jazyki. Awtorefierat dis. [...] kand. fitoł. nauk. Minsk: Biełorusskij gosudarstwiennyj uniwiersitiet. [Хацкевич, Вера. (1956). Суффиксальное словообразование существительных (суффиксы лица) в современном белорусском языке. Автореферат дис. [...] канд. филол. наук. Минск: Белорусский государственный университет].

Chomko, Jolanta. (2007). Polskie i białoruskie nazwy zawodów w ujęciu konfrontatywnym. U: Swiatłana Musijenka, Iwan Krenia (red.). Szlach da uzajemnasci. Materyjały XIV Miżnarodnaj nawukowaj kanfierencyi (s. 188-193). Hrodna: Hrodzienski dziarżauny uniwiersitet imia Janki Kupały. [Chomko, Jolanta. (2007). Polskie i białoruskie nazwy zawodów w ujęciu konfrontatywnym. У: Святлана Мусіенка, Іван Крэня (рэд.). Шлях да ўзаемнасиі. Матэрыялы ХIV Міжнароднай навуковай канферэниыл (s. 188-193). Гродна: Гродзенскі дзяржаўны ўніверсітэт імя Янкі Купалы].

Goral, Agnieszka. (2011). Dublety słowotwórcze wśród osobowych nazw subiektów czynności we współczesnym języku białoruskim. Studia Białorutenistyczne, 5, s. 395-413.

Goral, Agnieszka. (2013a). Derywacja sufiksalna osobowych nazw subiektów czynności w języku białoruskim. Lublin: Wydawnictwo UMCS.

Goral, Agnieszka. (2013b). „Nomina subiecti" w języku polskim i białoruskim. Kwestie dyskusyjne. W: Jolanta Panasiuk, Tomasz Woźniak (red.). Język-człowiek-społeczeństwo (s. 31-49). Lublin: Wydawnictwo UMCS.

Gorbaczik, Nikołaj. (1993). Nazwanija lic po riemiestu i profiesii w biełorusskom jazykie. Awtorefierat dis. [...] kand. fitoł. nauk. Minsk: AN Biełarusi, In-t jazykoznanija im. J. Kołasa (Na prawach rukopisi). [Горбачик, Николай. (1993). Названия лии по ремеслу и професии в белорусском языке. Автореферат дис. [...] канд. филол. наук. Мінск: АН Беларуси, Ин-т языкознания им. Я. Коласа (На правах рукописи)].

Jakowlewa, Anna. (2010). Nominacyi lic po profiessionalnoj prinadleżnosti w sowriemiennom russkom jazykie (siemanticzeskije osobiennosti i puti formirowanija). Awtorefierat dis. [...] kand. fitoł. nauk. Jarosławl: Jarosławskij gosudarstwiennyj piedagogiczeskij uniwiersitiet imieni K. D. Uszynskogo. [Яковлева, Анна. (2010). Номинации лици по профессиональной принадлежности в современном русском языке (семантические особенности и пути формирования). Автореферат дис. [...] канд. филол. наук. Ярославль: Ярославский государственный педагогический университет имени К. Д. Ушинского].

Kaliszan, Jerzy. (2000). Synonimia słowotwórcza rzeczowników w języku polskim i rosyjskim (na materiale nazw osób, czynności i cech abstrakcyjnych). Poznań: Uniwersytet im. Adama Mickiewicza. 
Łukaszaniec Aleksandr, Nikołajewa Olha (red.). (2014). Sopostawitelnoje opisanije russkogo i biełorusskogo jazykow. Słowoobrazowanije. Minsk: Biełaruskaja nawuka. [Лукашанец Александр, Николаева Ольга (ред.). (2014). Сопоставительное описание русского и белорусского языков. Словообразование. Минск: Беларуская навука].

Łukaszaniec, Alaksandr. (2001). Stowautwarennie i hramatyka. Minsk: Prawa i ekanomika. [Лyкашанец, Аляксандр. (2001). Словаўтварэнне і граматыла. Мінск: Права і эканоміка]. Łukaszaniec, Alaksandr. (2009). Pracesy internacyjanalizacyi u biełaruskaj mowie kanca XXpaczatku XXI stst. W: Elena Koriakowcewa (red.). Przejawy internacjonalizacji w językach słowiańskich (s. 111-125). Siedlce: Wydawnictwo Akademii Podlaskiej. [Лукашанец, Аляксандр. (2009). Працэсы інтэрнацыяналізацыі ў беларускай мове канца XXпачатку XXI стст. W: Elena Koriakowcewa (red.). Przejawy internacjonalizacji w językach słowiańskich (s. 111-125). Siedlce: Wydawnictwo Akademii Podlaskiej].

Łukaszaniec, Alaksandr. (2013). Prablemy suczasnaha biełaruskaha słowautwarennia. Minsk: Biełaruskaja nawuka. [Лукашанец, Аляксандр. (2013). Праблемы сучаснага беларускага словаўтварэння. Мінск: Беларуская навука].

Maczaława, Alena. (2013). Najmienni asoby u biełaruskaj $i$ anhlijskaj mowach: siemantyka i struktura. Hrodna: HrDU. [Мачалава, Алена. (2013). Найменні асобы у беларускай і англійскай мовах: семантыка і структура. Гродна: ГрДУ].

Maksimow, Władimir. (1975). Suffiksalnoje słowoobrazowanije imien suszczestwitielnych w russkom jazykie. Leningrad: Izd-wo Leningr. uniwiersitieta. [Максимов, Владимир. (1975). Суффиксальное словообразование имен существительных в русском языке. Ленинград: Изд-во Ленингр. университета].

Rusak, Walancina. (2002). Liniejnyja i nieliniejnyja marfałahicznyja zmieny asnou utwaralnych słou. Biełaruskaja linhwistyka, 52, s. 16-26. [Русак, Валянціна. (2002). Лінейныя і нелінейныя марфалагічныя змены асноў утваральных слоў. Беларуская лінгвістыка, 52 , c. 16-26].

Rusak, Walancina. (2003a). Marfanałohija addziejasłounaha sufiksalnaha słowautwarennia. Biełaruskaja linhwistyka, 53, s. 13-24. [Русак, Валянціна. (2003a). Марфаналогія аддзеяслоўнага суфіксальнага словаўтварэння. Беларуская лінгвістыка, 53, с. 13-24].

Rusak, Walancina. (2003b). Marfanałohija suczasnaj biełaruskaj mowy. Minsk: Biełaruskaja nawuka. [Русак, Валянціна. (2003б). Марфаналогія сучаснай беларускай мовы. Мінск: Беларуская навука].

Sajewicz, Michał. (2002). Derywacja sufiksalna osobowych nazw subiektów w nadnarwiańskich gwarach białoruskich Białostocczyzny. Deverbativa, deadiectiva. Lublin: Wydawnictwo Uniwersytetu Marii Curie-Skłodowskiej.

Siehień, Ludmiła. (2007). Ahulnaje ispiecyficznaje u słowautwaralnych sistemach polskaj i biełaruskaj mou (na materyjale nazounikau, jakija abaznaczajuć wykanaucu dziejannia). Studia Wschodniostowiańskie, 7, s. 357-370. [Сегень, Людміла. (2007). Агульнае і спецыфічнае ў словаўтваральных сістэмах польскай і беларускай моў (на матэрыяле назоўнікаў, якія абазначаюць выканаўцу дзеяння). Studia Wschodniostowiańskie, 7, s. 357-370]. 
Smułkowa, Elżbieta. (1992). Białorusko-polskie a białorusko-rosyjskie pogranicze językowe. W: Kwiryna Handke (red.). Stowiańskie pogranicza językowe (s. 143-151). Warszawa: „Ress Publica Press”.

Waranowicz, Waleryj. (1997). Asabowyja sufiksalnyja addziejasłounyja nazouniki u suczasnaj biełaruskaj litaraturnaj mowie. Wiesnik BDU, 4, s. 167-178. [Варановіч, Валерый. (1997). Асабовыя суфіксальныя аддзеяслоўныя назоўнікі ў сучаснай беларускай літаратурнай мове. Веснік БДУ, 4, с. 167-178].

Waranowicz, Waleryj. (2005). Stowautwarennie nazounikau u biełaruskaj mowie. Hrodna: HrDU. [Варановіч, Валерый. (2005). Словаўтварэнне назоўнікай у беларускай мове. Гродна: ГрДУ].

Waszakowa, Krystyna. (1994). Tendencje rozwojowe współczesnej polszczyzny końca XX w. W: Stanisław Gajda, Zbigniew Adamiszyn (red.). Przemiany współczesnej polszczyzny, materiały konferencji naukowej (s. 53-60). Opole: Wyższa Szkoła Pedagogiczna im. Powstańców Śląskich.

Witkowski, Wiesław. (1955). Sufiksy „nomina agentis” w języku rosyjskim. Studia z Filologii Polskiej i Stowiańskiej, 1, s. 486-520.

Władimirowa, Łarisa. (1991). Konfiksalnyje obrazowanija s finalnym -nik w istorii russkogo jazyka.Awtorefieratdis. [...] kand.fitot.nauk. Kazan:Kazanskijuniwiersitiet. [Владимирова, Лариса. (1991). Конфиксальные образования с финальным -ник в истории русского языка. Автореферат дис. [...] канд. филол. наук. Казань: Казанский университет].

Data nadesłania tekstu: 31.07 .2018 